\title{
Magnetite Nanoparticles and Spheres for Chemo- and Photothermal Therapy of Hepatocellular Carcinoma in vitro
}

This article was published in the following Dove Press journal: International Journal of Nanomedicine

\author{
Artur Jędrzak ${ }^{1,2}$ \\ Bartosz F Grześkowiak' \\ Klaudia Golba (D) \\ Emerson Coy (D) \\ Karol Synoradzki (D) ${ }^{1,3}$ \\ Stefan Jurga $\mathbb{D}^{\prime}$ \\ Teofil Jesionowski (iD) ${ }^{2}$ \\ Radosław Mrówczyński (D) \\ 'NanoBioMedical Centre, Adam \\ Mickiewicz University in Poznan, Poznan \\ PL-6I6|4, Poland; ${ }^{2}$ Institute of Chemical \\ Technology and Engineering, Faculty of \\ Chemical Technology, Poznan University \\ of Technology, Poznan PL-60965, Poland; \\ ${ }^{3}$ Institute of Molecular Physics Polish \\ Academy of Sciences, Poznan PL-60179, \\ Poland
}

Introduction: We present a multimodal nanoplatforms for the treatment of hepatocellular carcinoma (HCC) in vitro. The nanoplatforms are based on polydopamine (PDA)-coated magnetite nanoparticles (NPs) and spheres (sMAG) with PAMAM dendrimers and functionalized with NHSPEG-Mal ( $N$-hydroxysuccinimide-polyethylene glycol-maleimide) linker, which allows their functionalization with a folic acid derivative. The nanomaterials bearing a folic acid-targeting moiety show high efficiency in killing cancer cells in the dual chemo- and photothermal therapy (CT-PTT) of the liver cancer cells in comparison to modalities performed separately.

Materials and Methods: All materials are characterized in detail with transmission electron microscopy, Fourier transform infrared spectroscopy, thermogravimetric analysis, zeta potential and magnetic measurements. Also, photothermal properties were determined under irradiation of nanoparticles with laser beam of $2 \mathrm{~W} / \mathrm{cm}^{2}$. The nontoxicity of nanoparticles with doxorubicin and without was checked by WST and LIVE/DEAD assay. Those tests were also used to evaluate materials bearing folic acid and anticancer drug in combined chemo- and photothermal therapy of HCC. Further, the generation of reactive oxygen species profile was also evaluated using flow cytometry test.

Results: Both NPs and sMAG showed high photothermal properties. Nevertheless, the higher photothermal response was found for magnetic spheres. Materials of concentration above $10 \mu \mathrm{g} /$ $\mathrm{mL}$ reveal that their activity was comparable to free doxorubicin. It is worth highlighting that a functionalized magnetic sphere with DOXO more strongly affected the HepG2 cells than smaller functionalized nanoparticles with DOXO in the performed chemotherapy. This can be attributed to the larger size of particles and a different method of drug distribution. In the further stage, both materials were assessed in combined chemo- and photothermal therapy (CT-PTT) which revealed that magnetic spheres were also more effective in this modality than smaller nanoparticles.

Conclusion: Here, we present two types of nanomaterials (nanoparticles and spheres) based on polydopamine and PAMAM dendrimers g.5.0 functionalized with NHS-PEG-Mal linker terminated with folic acid for in vitro hepatocellular carcinoma treatment. The obtained materials can serve as efficient agents for dual chemo- and photothermal therapy of HCC. We also proved that PDA-coated magnetic spheres were more efficient in therapies based on near-infrared irradiation because determined cell viabilities for those materials are lower than for the same concentrations of nanomaterials based on small magnetic nanoparticles.

Keywords: magnetic nanoparticles, polydopamine, liver cancer, drug delivery

\section{Introduction}

Hepatocellular carcinoma (HCC) is one of the most common kinds of liver cancer. HCC mainly occurs in people who suffer from chronic liver diseases, such as cirrhosis
Correspondence: Radosław Mrówczyński NanoBioMedical Centre, Adam Mickiewicz University in Poznan, Wszechnicy

Piastowskiej 3, Poznan PL-6I6I4, Poland Tel +48618296709

Email radoslaw.mrowczynski@amu.edu.pl
International Journal of Nanomedicine 2020:15 7923-7936

7923

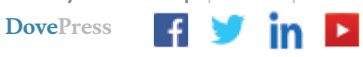

(c) (i) (5) 2020 Jedrzak et al. This work is published and licensed by Dove Medical Press Limited. The full terms of this license are available at https://www.dovepress.com/terms. BY NC php and incorporate the Creative Commons Attribution - Non Commercial (unported, v3.0) License (http:///creativecommons.org/licenses/by-nc/3.0/). By accessing the work you hereby accept the Terms. Non-commercial uses of the work are permitted without any further permission from Dove Medical Press Limited, provided the work is properly attributed. For permission for commercial use of this work, please see paragraphs 4.2 and 5 of our Terms (https://www.dovepress.com/terms.php). 
of the liver. Hepatitis B or hepatitis C are also reported as leading causes of diseases ${ }^{1-3}$ as well as non-alcoholic fatty liver disease (NAFLD), obesity, type 2 diabetes, smoking and heavy alcohol use. ${ }^{1-6}$ Research conducted by the WHO indicates that the number of cases of liver cancer from year to year is increasing. The mortality caused by liver cancer has increased by around $50 \%$ in the last decade. Only in 2018, 782,000 deaths were reported. As a result, HCC has become the sixth most common cancer worldwide, becoming the third cause of death from cancer per year.

Nowadays, only a few modalities are applied in liver cancer therapy including surgical resection, liver transplantation and chemotherapy. However, all of them have some disadvantages. For instance, liver transplantation is chosen only for a few patients with HCC, because of the high cost and shortage of liver donors. Surgical resection has been widely proven to improve patients' lifespan with either HCC or liver metastases, particularly those with colorectal cancer liver metastases. The last method implemented in curing $\mathrm{HCC}$ is routine chemotherapy that generates side effects, decreases patient comfort and makes patients deteriorate. $^{3-7}$

Because the aforementioned methods have clear limitations and show side effects, it is desirable to look for solutions, especially those offering targeted therapy, to improve patient life comfort and enhanced therapeutic outcome. Therefore, there are big expectations for nanotechnology, which is supposed to increase the efficiency of existing methods and develop novel alternative modalities, reducing or avoiding unwanted side effects and toxicity to healthy cells. ${ }^{8-11}$ This is mostly realized by tailoring and synthesis of multimodal drug carriers for anticancer therapy based on nanomaterials. Two of the most promising nanomaterials employed in the field of multifunctional nanomaterials for cancer treatment are magnetic nanoparticles (NPs) and spheres (sMAG) of iron oxides. They have drawn much attention because they exhibit high biocompatibility, biodegradability, nontoxicity and can be manipulated by an external magnetic field. They are size-/ shape-tunable and show a large surface area due to the high surface to volume ratio. ${ }^{11-13}$

Moreover, magnetite additives can be used as contrast agents in magnetic resonance imaging (MRI), which make them a versatile component for constructing a theranostic tool for nanomedicine. ${ }^{13-18}$ Indeed, bare magnetic nanoparticles were exploited in the preparation of drug carriers. However, their multifunctional character is still not fully explored because they are not often merged with other modalities, ie photothermal therapy (PTT), which could improve the therapeutic outcome in anticancer therapies.

Although PTT is still in early stage of development, the application of light-induced heating nanoparticles is of great interest in the area of modern nanomaterials for cancer therapy. ${ }^{19-21}$ What is more, it has been shown that combined chemo- and photothermal therapy leads to improved therapeutic effect and diminishes the probability of cancer regression. ${ }^{22}$ It has been demonstrated that both bare magnetic nanoparticles and magnetic spheres show weak photothermal responses so their photothermal properties have to be enhanced in order to fully exploit the potential of these magnetic nanostructures in advanced cancer therapy. ${ }^{23-26}$ It is worth highlighting that photothermal properties of magnetic spheres are higher than regular magnetic nanoparticles, but in both cases they need to be improved for application in photothermal therapy. $^{27,28}$

Polydopamine (PDA) is a mussel-inspired polymer which was reported for the first time by Lee et al in $2007 .^{29}$ Since that time it has found wide application in many areas of material chemistry and nanomedicine. ${ }^{30-33}$ Successful use of PDA for the construction of intriguing materials can be attributed to a set of unique features. Firstly, PDA possesses strong adhesive properties, which allow virtually any type of material to be covered, including hydrophobic surfaces, noble metals and different groups of nanoparticles. ${ }^{34}$ Secondly, PDA coating has been proved to be biocompatible. ${ }^{33}$ Finally, PDA shows outstanding photothermal properties due to its superior absorption coefficient $\left(7.310^{8} \mathrm{M}^{-1} \mathrm{~cm}^{-1}\right)$, photothermal efficiency (about 40\%) at $808 \mathrm{~nm}$ and improved stability under near-infrared (NIR) irradiation. ${ }^{35}$ Therefore, PDA has attracted the attention of many scientific groups as a promising material for the preparation of multifunctional nanomaterials for cancer therapy, and has been extensively used in this area, especially in the last five years. ${ }^{36,37}$ As a matter of fact, a PDA shell was deposited on magnetic nanoparticles or magnetic spheres improving their photothermal properties, which rendered them into strong photothermal agents for cancer therapy. ${ }^{38-40}$ It has been shown that magnetic nanoparticles with PDA coating can serve as a drug delivery system for doxorubicin to HeLa cancer cells. ${ }^{41}$ However, the majority of PDA-coated magnetic nanostructures use passive targeting for cancer cells and particularly their application in HCC treatment has not been thoroughly investigated. 
Herein we present the synthesis and application of new nanoplatforms for in vitro dual chemo - and photothermal therapy of HCC based on PDA-coated magnetite nanoparticles (NPs) and spheres (sMAG) functionalized with folic acid. We also demonstrate a versatile approach toward surface functionalization of nanomaterials using a bifunctional linker that allows potential modification of nanomaterials with thiol derivatives of other biological entities. In the end, we discuss the generation of reactive oxygen species (ROS) during the PTT process. Thus, our research brings new solutions in the field of nanomedicine and surface chemistry of nanomaterials, where both synthesis and structure of nanomaterials are crucial in order to tailor biological properties.

\section{Materials and Methods}

The reagents used in this work were iron(III) chloride hexahydrate (97\%), iron(II) chloride tetrahydrate (97\%), ammonium solution (25\%), citric acid ( $>99 \%)$, sodium citrate, dopamine hydrochloride (99\%), PAMAM dendrimers g.5.0 (5 wt.\% in methanol), phosphate buffered saline (PBS; $\mathrm{pH}=6.8$ or $7.4 ; 10 \mathrm{mM}$ ), sodium tetraphenylborate $(\mathrm{NaB} ; \mathrm{pH}=8.5 ; 10 \mathrm{mM}$ ), Tris aminomethane buffer (Tris; $\mathrm{pH}=8.5 ; 10 \mathrm{mM})$, doxorubicin hydrochloride $(>99 \%)$ (Doxo $\cdot \mathrm{HCl}), O-\left[N-\left(3\right.\right.$-maleimidopropionyl)aminoethyl]- $O^{\prime}$ -[3-( $N$-succinimidyloxy)-3-oxopropyl]heptacosaethylene glycol (>90\%). All of the chemical reagents were purchased from Sigma-Aldrich, except for the dopamine hydrochloride (Alfa Aesar) and doxorubicin hydrochloride (LC Laboratories). All reagents and solvents were of reagentgrade quality.

\section{Synthesis of Material AI-A4 and BI-B4 Synthesis of NPs@PDA@DD5 (Material A2)}

Briefly, NPs@PDA (material A1) was synthesized according to the previously reported protocol. ${ }^{38}$ The material A1 $(10 \mathrm{mg})$ was mixed with PAMAM dendrimers g.5.0 (DD5) (2.5 mg; $0.09 \mathrm{mM})$ in Tris buffer $(20 \mathrm{~mL} ; \mathrm{pH}=8.5 ; 10 \mathrm{mM})$ in RT, for $4 \mathrm{~h}$. Then, the nanoparticles were collected by an external magnet and washed with methanol and water $(1: 1 ; 3$ $\times 10 \mathrm{~mL})$, and suspended in the Milli-Q water $(10 \mathrm{~mL})$.

\section{Synthesis of sMAG@PDA@DD5 (Material B2)}

Briefly, iron(III) chloride hexahydrate $(0.54 \mathrm{~g} ; 2 \mathrm{mM})$; sodium acetate $(1.5 \mathrm{~g} ; 18.3 \mathrm{mM})$; sodium acrylate $(1.5 \mathrm{~g}$; $16 \mathrm{mM})$; ethylene glycol $(5 \mathrm{~mL})$; diethylene glycol $(15 \mathrm{~mL})$ were mixed together on a magnetic stirrer. ${ }^{42}$ After several minutes of stirring, the suspension was poured into the Teflon ${ }^{\circledR}$ deposit with volume $(50 \mathrm{~mL})$ and then it was enclosed in stainless steel armour. It was put in aa autoclave pre-heated to $200^{\circ} \mathrm{C}$ for $10 \mathrm{~h}$. Then, it was cooled to ambient temperature, and rinsed with $40 \mathrm{~mL}$ of $\mathrm{EtOH}$ and $100 \mathrm{~mL}$ water. The magnetic nanospheres (sMAG; material B) were very stable and could be collected by centrifugation. To cover the spheres with polydopamine, material B (50 mg), dopamine hydrochloride $(50 \mathrm{mg} ; 0.26 \mathrm{mM})$, Tris buffer $(25 \mathrm{~mL})$ and water $(25 \mathrm{~mL})$ were mixed on the magnetic stirrer with air-access in ambient temperature for $4 \mathrm{~h}$. Then, nanomaterial B1 was collected by an external magnet and washed with water $(3 \times 20 \mathrm{~mL})$, and suspended in the Milli-Q water $(20 \mathrm{~mL})$.

The obtained sMAG@PDA (10 mg) (material B1)was mixed with PAMAM DD5 (5 mg; $0.09 \mathrm{mM})$ in $20 \mathrm{~mL}$ of Tris buffer for $4 \mathrm{~h}$. Then, the sMAG@PDA@DD5 was collected by an external magnet and washed with methanol and water $(1: 1 ; 3 \times 10 \mathrm{~mL})$, and suspended in the Milli-Q water $(10 \mathrm{~mL})$.

\section{Synthesis of NPs@PDA@DD5@NHS-PEG-Mal-FA} (Material A3) and sMAG@PDA@DD5@NHS-PEGMal-FA (Material B3)

Material A2 or B2 $(20 \mathrm{mg})$ was mixed with $\mathrm{NaB}$ buffer $(40 \mathrm{~mL})$ and NHS-PEG-Mal linker (40 mg; $0.025 \mathrm{mM}$ ) in DMSO $(4 \mathrm{~mL})$ for $2.5 \mathrm{~h}$ in ambient temperature. Next, the reaction medium was changed to PBS buffer $(\mathrm{pH}=6.8)$. Subsequently, thiol-derivative of folic acid (SH-FA) (20 mg; $0.04 \mathrm{mM}$ ) (see SI for Preparation of SH-FA derivative) were dissolved in DMSO $(2 \mathrm{~mL})$ and added to the material $\mathrm{A} 2$ or B2; the reaction was carried out all night; the resulting products were washed with methanol and water $(1: 1 ; 3 \times$ $10 \mathrm{~mL})$, and suspended in the Milli-Q water $(10 \mathrm{~mL})$.

Synthesis of NPs@PDA@DD5@NHS-PEG-Mal-FADoxo (Material A4) and sMAG@PDA@DD5@NHS-PEG-Mal-FA-Doxo (Material B4)

Material A3 and B3 $(2 \mathrm{mg})$ were added to $2 \mathrm{~mL}$ of doxorubicin solution $(1 \mathrm{mg} / \mathrm{mL})$ in PBS $(10 \mathrm{mM}, \mathrm{pH}=7.4)$. Each mixture was shaken at $23^{\circ} \mathrm{C}$ for $24 \mathrm{~h}$ to obtain materials $\mathrm{A} 4$ and B4. Then, the nanocarriers were collected by external magnet and washed with PBS $(2 \times 2 \mathrm{~mL})$. After that, materials $\mathrm{A} 4$ and $\mathrm{B} 4$ were ready to drug-release or for biological tests.

\section{Materials Characterization}

Transmission electron microscopy (TEM) micrographs were recorded on a JEM-1400 microscope made by JEOL (Japan) working at an accelerating voltage of $120 \mathrm{kV}$. 
Samples were drop casted on a copper grid (Formvar/ Carbon) made by TedPella (USA).

Fourier transform infrared spectroscopy (FTIR) spectra were recorded on Vertex 70 (Germany) in KBr pellets (FTIR grade). Zeta potentials and hydrodynamic diameter, polydispersity index (PDI) by Zetasizer Nano ZS made by Malvern Instruments Ltd (United Kingdom) were determined. Thermogravimetric analysis (TGA) using a Jupiter STA 449 F3 instrument (Netzsch, Germany) was carried out. UVVis measurements on Perkin-Elmer Lambda 950 UV/Vis/ NIR were performed. Magnetic measurements in the were recorded in a temperature range $2-300 \mathrm{~K}$ and magnetic fields up to $5 \mathrm{~T}$ using a Quantum Design (USA) PPMS vibrating sample magnetometer (VMS). Temperature dependence of magnetization $\mathrm{M}(\mathrm{T})$ was measured in zero-field cooling (ZFC) and field cooling (FC) mode in a magnetic field of $0.1 \mathrm{~T}$. Magnetization curves $\mathrm{M}(\mathrm{H})$ were obtained at 4 and 300 K. Photostability and photothermal tests of materials A3, A4, B3, B4 with a NIR laser at $808 \mathrm{~nm}$ wavelength and power of 1, 2, 3 W (Changchun New Industries Optoelectronics Tech. Co., Ltd., China) were performed. The temperature of the solutions into a quartz cuvette $(1 \mathrm{~mL})$ by a digital thermometer with a thermocouple sensor was measured.

\section{Release of Doxorubicin from Materials A4 and B4}

The profile of Doxo-release from materials A4 and B4 was performed according to the following procedure. Two milligrams of the nanomaterial was mixed with $2 \mathrm{~mL}$ citric buffer $(10 \mathrm{mM}, \mathrm{pH}=4.5)$ or with $2 \mathrm{~mL}$ PBS $(10 \mathrm{mM}$, pH $=7.4$ ) at $37^{\circ} \mathrm{C}$ to determine the effect of $\mathrm{pH}$ on the release. Then, each of the samples was collected at appropriate time intervals, followed by re-filling the mixture with a fresh buffer portion. The amount of free doxorubicin in the supernatants was analyzed by UV-Vis spectroscopy at $486 \mathrm{~nm}$ wavelength.

\section{Cell Culture}

HepG2 hepatocellular carcinoma cell line and THLE-2 epithelial cell line isolated from the human liver were purchased from American Type Culture Collection (ATCC). HepG2 cells were cultured in a Minimum Essential Medium Eagle (MEM, Sigma-Aldrich) medium supplemented with $10 \%$ fetal bovine serum (FBS, SigmaAldrich), $1 \%$ antibiotics (penicillin $100 \mu \mathrm{g} / \mathrm{mL}$, streptomycin $100 \mu \mathrm{g} / \mathrm{mL}$, Sigma-Aldrich), non-essential amino acids (Sigma-Aldrich) and sodium pyruvate (Sigma-Aldrich).
THLE-2 cells were cultured in a BEBM medium supplemented with BEGM Bullet Kit, 10\% FBS and 1\% antibiotics. The flasks and plates for the THLE-2 culturing were precoated with a mixture of $0.01 \mathrm{mg} / \mathrm{mL}$ fibronectin, $0.03 \mathrm{mg} / \mathrm{mL}$ bovine collagen type $\mathrm{I}$ and $0.01 \mathrm{mg} / \mathrm{mL}$ bovine serum albumin dissolved in MEM medium. Both cell lines were maintained at $37^{\circ} \mathrm{C}$ in a $5 \% \mathrm{CO}_{2}$ humidified environment.

\section{Cytotoxicity Assays}

The WST-1 cell proliferation assay and the Live/Dead cell viability assay were performed to assess the cytotoxicity of the synthesized nanoparticles. In the WST-1 assay HepG2 and THLE- 2 cells were seeded at densities of $3 \times 10^{4}$ and $5 \times 10^{3}$ cells per well in the 96 -well plate, respectively. After $24 \mathrm{~h}$, the increasing concentrations of tested nanoparticles $(1.25-40 \mu \mathrm{g} / \mathrm{mL})$ were added to each well, and the cells were incubated for $48 \mathrm{~h}$. Next, the cells were washed with DPBS and $200 \mu \mathrm{L}$ of fresh medium was added to each well. Then, $10 \mu \mathrm{L}$ of the WST-1 Cell Proliferation Reagent was added to each well and incubated for $4 \mathrm{~h}$. After this time, $100 \mu \mathrm{L}$ of supernatant was transferred to fresh wells, and the absorbance at $450 \mathrm{~nm}$ (reference wavelength 620 $\mathrm{nm}$ ) was recorded against the background control, using a multi-well plate reader (Zenyth, Biochrom). The cell viability was expressed as the respiration activity normalized to untreated cells. All experiments were carried out in triplicates.

In the Live/Dead cell viability assay THLE-2 cells were seeded at a density of $1 \times 10^{4}$ cells per well in black polystyrene 96-well flat bottom plates with a transparent bottom (Greiner Bio-One $\mathrm{GmbH}$ ) precoated with the coating solution containing $0.01 \mathrm{mg} / \mathrm{mL}$ fibronectin, $0.03 \mathrm{mg} / \mathrm{mL}$ bovine collagen type I and $0.01 \mathrm{mg} / \mathrm{mL}$ bovine serum albumin dissolved in MEM medium. Following $48 \mathrm{~h}$ exposure to the nanoparticles, cells were incubated with $2 \mu \mathrm{M}$ calcein AM, $2 \mu \mathrm{M}$ ethidium homodimer- 1 and $8 \mu \mathrm{M}$ Hoechst 33,342 (ThermoFisher Scientific) containing DPBS (100 $\mu \mathrm{L} /$ well) for 30 minutes at $37^{\circ} \mathrm{C}$. Finally, the cells were analyzed with the IN Cell Analyzer 2000 (GE Healthcare Life Sciences). Viable cells were imaged using the FITC/FITC excitation/ emission filters while for the dead cells, the TexasRed/ TexasRed ex/em filter combination was applied. DAPI/ DAPI was used to detect the Hoechst 33,342 blue signal. A minimum of 20 fields was imaged per well with a $20 \times$ magnification. Analysis of the collected images was performed with the IN Cell Developer Toolbox software (GE Healthcare Life Sciences) using an in-house developed 
protocol. First, the total cell number was retrieved from the DAPI images using defining and counting the nuclei. Subsequently, the number of viable cells from the FITC images and the number of dead cells from the TexasRed images were determined.

\section{Photothermal Therapy (PTT) Cell Viability Assays}

To verify the cell viability after laser irradiation, HepG2 cells seeded at a density of $3 \times 10^{4}$ cells per well in 96-well plates with increasing concentration of materials A3 and B3 were incubated. After $4 \mathrm{~h}$ of incubation, cells were irradiated by $808 \mathrm{~nm}$ laser with power densities of $2 \mathrm{~W} / \mathrm{cm}^{2}$ for $5 \mathrm{~min}$. The cells were further incubated for $48 \mathrm{~h}$, and the WST-1 cell viability assay was carried out as described above. To visualize live and dead cells, HepG2 cells seeded at a density of $1.2 \times 10^{5}$ cells per well in 24-well plates coated with $0.01 \%$ poly-L-lysine (Sigma-Aldrich) were incubated with $40 \mu \mathrm{g} / \mathrm{mL}$ of materials $\mathrm{A} 3$ and B3. After $4 \mathrm{~h}$ of incubation, the cells were irradiated by $808 \mathrm{~nm}$ laser with power densities of $2 \mathrm{~W} / \mathrm{cm}^{2}$ for $5 \mathrm{~min}$. After another $24 \mathrm{~h}$, the cells were labelled with $2 \mu \mathrm{M}$ calcein $\mathrm{AM}$ and $2 \mu \mathrm{M}$ ethidium homodimer-1 containing DPBS $\left(250 \mu \mathrm{L} /\right.$ well) for $30 \mathrm{~min}$ at $37^{\circ} \mathrm{C}$. Finally, the cells were analyzed with the IN Cell Analyzer 2000 (GE Healthcare Life Sciences). To quantitatively measure cellular population undergoing oxidative stress based on detection of ROS, namely superoxide radicals, the Muse ${ }^{\circledR}$ Oxidative Stress Assay (Merck) was performed. HepG2 cells seeded at a density of $3 \times 10^{4}$ cells per well in 96-well plates with increasing concentration of materials $\mathrm{A} 3$ and $\mathrm{B} 3$ were incubated. After $4 \mathrm{~h}$ of incubation, cells were irradiated by 808 $\mathrm{nm}$ laser with power densities of $2 \mathrm{~W} / \mathrm{cm}^{2}$ for $5 \mathrm{~min}$. Assay was carried out immediately $(0 \mathrm{~h})$ or $24 \mathrm{~h}$ after laser irradiation. Then, the cells were trypsinized, centrifuged and resuspended in $1 \times$ Assay Buffer. Next, $10 \mu \mathrm{L}$ of cell in suspension was mixed with $190 \mu \mathrm{L}$ of the MUSE $^{\circledR}$ Oxidative Stress working solution followed by 30 minincubation at $37^{\circ} \mathrm{C}$ in the dark. The stained cells were then analyzed using MUSE $^{\circledR}$ Cell Analyzer.

\section{Combined Chemo- and Photothermal Therapy (CT-PTT) Cell Viability Assays}

To verify the combined therapy effects, CT (chemotherapy) and PTT (photothermal therapy), HepG2 cells seeded at a density of $3 \times 10^{4}$ cells per well in 96-well plates were incubated with increasing concentrations of material A4 and B4. After $4 \mathrm{~h}$ of incubation, cells were irradiated by $808 \mathrm{~nm}$ laser with power densities of $2 \mathrm{~W} / \mathrm{cm}^{2}$ for $5 \mathrm{~min}$. The cells were further incubated for $48 \mathrm{~h}$, and the WST-1 cell viability assay was performed.

\section{Statistical Analysis}

All quantitative data are represented as the mean \pm standard deviation. Statistical analyses of cell viability results were performed using StatSoft Statistica 10 software (StatSoft Power Solutions, Inc., Tulsa, OK, USA) and factorial analysis of variance (ANOVA) with a Tukey's post-hoc significant difference test. Statistical significance was assumed for $p$-value $<0.05$.

\section{Results and Discussion Synthesis and Characterization of Materials (A - A4 and B - B4)}

The synthetic approach towards functionalized polydopamine (PDA)-coated magnetite nanoparticles (NPs) and spheres (sMAG) functionalized is presented in Figure 1.

Material A1 and material B1 were obtained via coprecipitation of magnetic NPs and the solvothermal reaction of sMAG from iron chloride salts and then followed by oxidative polymerization of dopamine hydrochloride in Tris buffer. Further, PAMAM dendrimers g.5.0 (DD5) were linked to material A1 and material B1 via Michael reaction. ${ }^{43}$ Resulting materials A2 and B2 were submitted to reaction with the NHS-PEG-Mal linker under controlled conditions to assure reaction of NHS groups with amino groups from PAMAM dendrimers and keeping active maleimide moieties ready for thiol-ene click reaction with thiol-derivative of folic acid. In the next step, materials A3 and B3 were loaded with doxorubicin, yielding material $\mathrm{A} 4$ and material $\mathrm{B} 4$.

The morphology of these nanomaterials was investigated utilizing TEM. Both A3 and B3 samples were spherical in shape and had size in a range of 8-14 $\pm 2 \mathrm{~nm}$ and 80-120 \pm $20 \mathrm{~nm}$, respectively (see Figure 2 and SI Figure 1). Further, we verified effective surface functionalization by measuring the zeta potential of nanoparticles (see Figure 3C). The zeta potentials of materials $\mathrm{A} 1$ and $\mathrm{B} 1$ were $-43.8 \pm 0.6$ and $-39.3 \pm 1.1 \mathrm{mV}$, respectively. After the PAMAM dendrimers attached to surfaces of materials A1 and B1, the zeta potential increased to $+7.5 \pm 0.6$ and $+19.1 \pm 2.5 \mathrm{mV}$, respectively. The change of electrokinetic potential from negative to positive was assigned to the attachment of PAMAM dendrimers to the PDA-coated nanostructures. After functionalization 

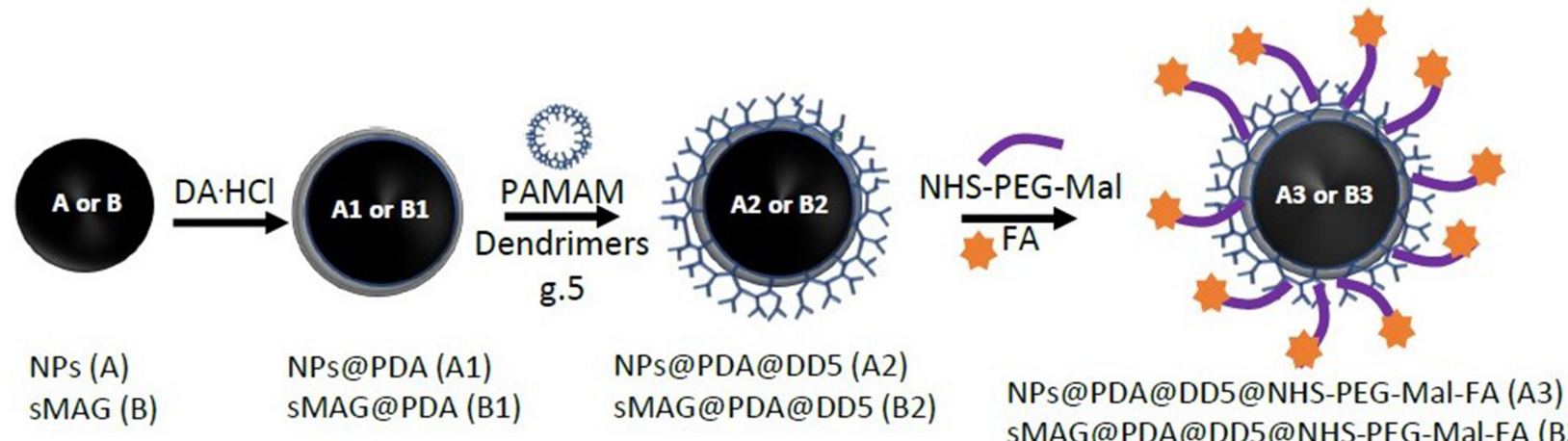

sMAG@PDA@DD5@NHS-PEG-Mal-FA (B3)

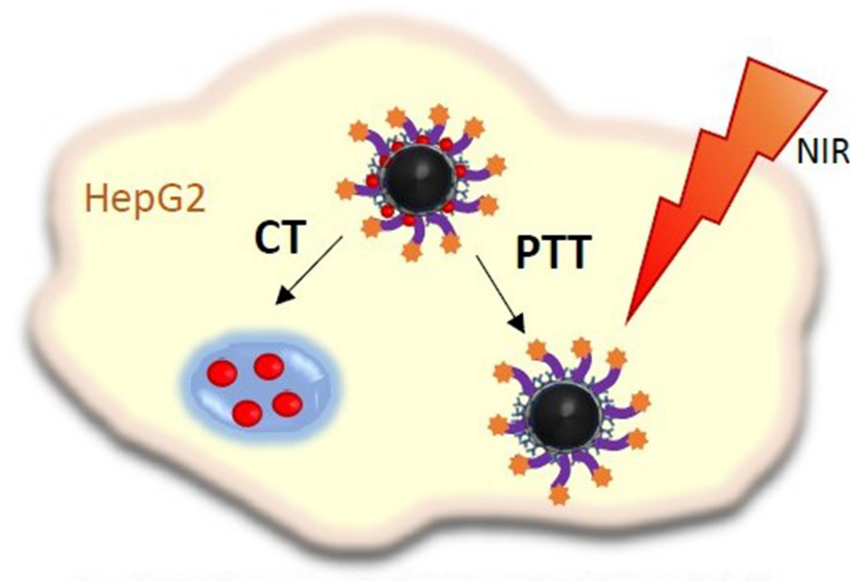

Combined chemo- (CT) and phototherapy (PTT)

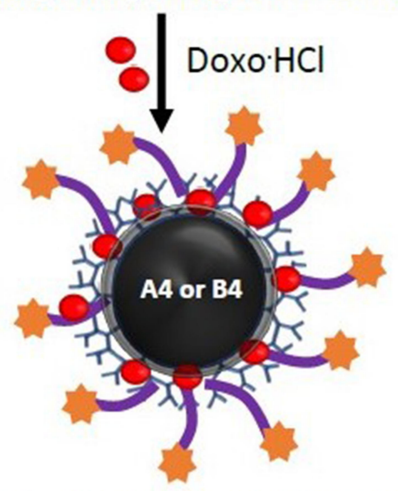

NPs@PDA@DD5@NHS-PEG-Mal-FA@Doxo(A4) sMAG@PDA@DD5@NHS-PEG-Mal-FA@Doxo (B4)

Figure I The synthesis scheme of NPs@PDA@DD5@NHS-PEG-Mal-FA@Doxo (A4) and sMAG@PDA@DD5@NHS-PEG-Mal-FA@Doxo (B4).

with linker and addition of folic acid to materials A2 and B2, zeta potential values decreased to $-23.1 \pm 1.9$ and $-15.8 \pm$ $1.8 \mathrm{mV}$, respectively. In this case, a change was observed due to the free carboxylic moiety in folic acid. FTIR spectra of samples A1-A3 and B1-B3 showed common characteristic bands of $\mathrm{Fe}-\mathrm{O}$ at $586 \mathrm{~cm}^{-1}$ and in a range of $1620-1440 \mathrm{~cm}^{-1}$ from polydopamine, which were assigned to $\mathrm{NH}-, \mathrm{C}-\mathrm{H}$ and $\mathrm{C}=\mathrm{C}, \mathrm{C}=\mathrm{O}$ group vibrations. However, detailed analysis was not possible due to the superimposing signal in the range mentioned above (see Figure 3A and B). To obtain information about organic content on nanoparticles and to confirm the functionalization with folic acid, we submitted all synthesized samples to TGA (see SI Figure 2a and $\underline{\text { SI Figure } 2 b)}$. These nanomaterials presented a slight weight loss of up to $150^{\circ} \mathrm{C}$, which was related to the water evaporation. Materials A1 and B1 lost about $20 \%$ of the initial mass in the whole range; up to $1000^{\circ} \mathrm{C}$, which was related to the thermal decomposition of the polydopamine. The $40 \%-50 \%$ mass loss of materials A2, A3 and B2, B3 in the temperature range between 200 and $750^{\circ} \mathrm{C}$ was related to the thermal decomposition of the polydopamine and PAMAM dendrimers with linker and FA. Materials A3 and B3 lost around
$4 \%$ and $10 \%$ more than materials $\mathrm{A} 2$ and $\mathrm{B} 2$, due to the higher amount of organic compounds. The results of magnetic measurements performed for A2, A3, B2, and B3 samples are summarized in SI Figure 3. The magnetization measured at RT as a function of the applied magnetic field strength indicates the non-hysteretic, superparamagnetic-like nature of studied materials. The same $\mathrm{M}(\mathrm{H})$ curves taken at 5 $\mathrm{K}$ revealed clear hysteresis, indicating that the samples are in the blocked state at this temperature. The saturation magnetization $\left(\mathrm{M}_{\mathrm{S}}\right)$ values, established as the highest value of magnetization at the magnetic field of $5 \mathrm{~T}$, are typical for hybrid materials containing nanoparticles of magnetite. ${ }^{44}$ Differences in $\mathrm{M}_{\mathrm{S}}$ values for different samples result from different magnetite content in each of them as can be inferred from SI Figure $3 \mathrm{~b}$. The obtained $\mathrm{M}(\mathrm{T})$ data do not show bifurcation - the ZFC and FC curves overlap almost perfectly. In all cases, the $M$ value increases with decrease of temperature, and there is no sign of Verwey's transition ${ }^{45}$ or blocking the process of particles. ${ }^{46}$ The obtained $\mathrm{M}(\mathrm{T})$ curves are typical of superparamagnetic particles in the high-field range. $^{46,47}$ Moreover, at temperatures below $30 \mathrm{~K}$, a clear upturn in the magnetization was recorded for A2, A3 and B2 
A

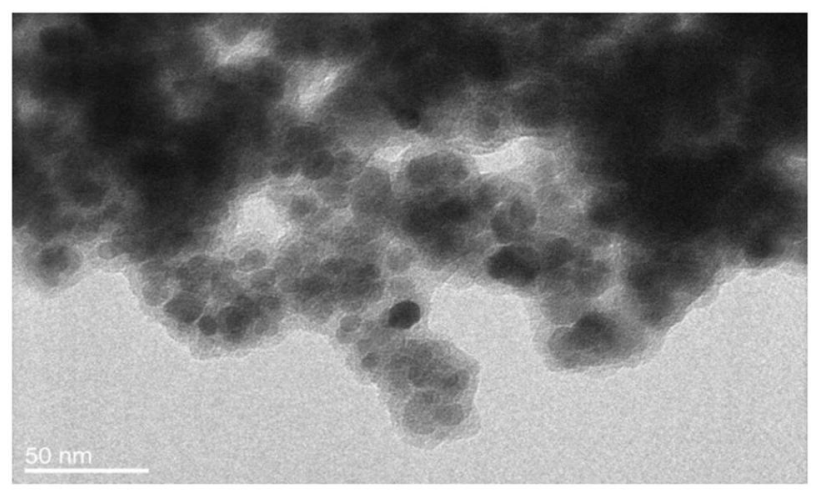

B

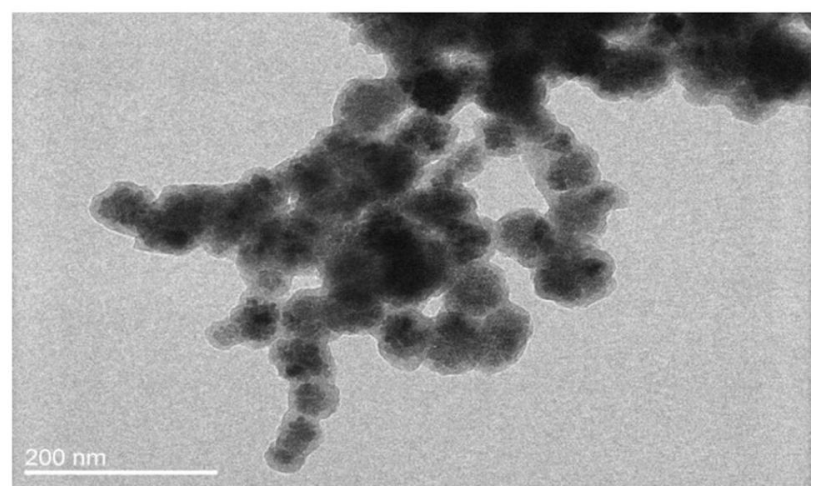

Figure 2 TEM micrographs of materials: A3 (A) and B3 (B).

samples. Such behavior has already been observed in other nanocomposite materials based on magnetite and may be related to the excitation of the spin waves in magnetite nanoparticles. ${ }^{47,48}$ The obtained results of the magnetic measurements show that all tested materials have similar superparamagnetic properties, confirming the small, nanometric size of our samples.

Becasue we planned to use our materials in photothermal therapy using NIR laser light, their UV-Vis spectra in a range 250-900 $\mathrm{nm}$ (Figure 4A) was measured. The performed experiments confirmed the absorption of nanomaterials in the region of interest. Moreover, the absorption value was higher for PDA-coated nanostructures than for pure magnetic materials. Further, to investigate photothermal properties of the $\mathrm{A} 3$ and $\mathrm{B} 3$ and to check if they can be used as efficient photothermal agents, we irradiated them with a laser beam of $808 \mathrm{~nm}$ at power 1,2 and $3 \mathrm{~W}$ for $500 \mathrm{~s}$ (Figure 4B and $\mathrm{C}$ and SI Figure 4). The temperature change of the nanoparticle's suspension in water was power- and concentration-dependent. The highest temperature change was recorded for nanomaterials irradiated with laser power of $3 \mathrm{~W}$ at the concentration of $100 \mu \mathrm{g} / \mathrm{mL}$ (24 and $28{ }^{\circ} \mathrm{C}$ for nanomaterials A3 and B3, respectively). At lower laser power $(2 \mathrm{~W})$ and the same concentration, the temperature change was equal to 16 and $19^{\circ} \mathrm{C}$ for material A3 and B3, respectively. It is essential to highlight that for both materials, the temperature increment recorded at a concentration of $25 \mu \mathrm{g} / \mathrm{mL}$ was higher than for pure magnetic materials at a concentration of 100 $\mu \mathrm{g} / \mathrm{mL}$. This phenomenon took place because, together with an increased mass of nanomaterials, we increased the content of PDA, which is mostly responsible for photothermal properties. Moreover, magnetic spheres rimmed with polydopamine (B3) caused a higher temperature increase in comparison to sample B2 at the same concentration. It is important to stress that the irradiation of pure water, with the same laser power, did not significantly influence water temperature. Finally, we carried out the photostability tests of materials A3 and B3, which prove that our materials could be used in at least 5 on/off cycles of laser irradiation (Figure 4D).

\section{Drug Loading and Release Profile}

An important issue in drug delivery using nanocarriers is determining the drug loading capacity and investigating its release profile from the carrier. In our case, we focused on doxorubicin, which is a standard anticancer drug, and can also be applied in HCC therapy. The loading tests were carried out at room temperature for $24 \mathrm{~h}$ in PBS buffer at $\mathrm{pH}=7.4$ as a medium to ensure the stability of both materials and drug. Further, the drug release profile was evaluated by incubation of the analyzed materials at a temperature of $37^{\circ} \mathrm{C}$, with citric buffer at $\mathrm{pH}=4.5$. The cumulative drug release after $120 \mathrm{~h}$ was $19.5 \%$ and $14.5 \%$ for material A4 and B4, respectively (see SI Table 1). These results indicate that our proposed materials A4 and B4 could release the drug in a slow and sustained way, which is a desirable feature in chemotherapy. Moreover, the observed drug release was $\mathrm{pH}$-dependent as only an insignificant amount of doxorubicin was released in $\mathrm{PBS}$ at $\mathrm{pH}=7$.4. In contrast, acidic $\mathrm{pH}$ enhanced the release of the chemotherapeutic drug from the carriers. During our experiments, the drug release from materials $\mathrm{A} 3$ and $\mathrm{B} 3$ as compared to nanomaterials bearing the PEG linker (A4 and B4) was measured. We found that the PEGylation of dendrimer sites resulted in higher drug release. This is probably because the PEG chains also contribute to drug loading. In acidic $\mathrm{pH}$, both PEG chains and amino groups from the PAMAM dendrimer are protonated, which results in 
A

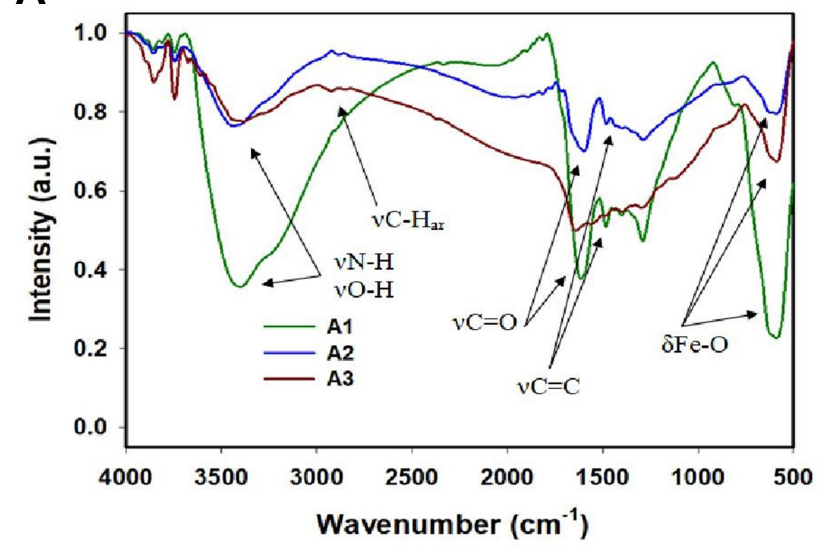

C
B

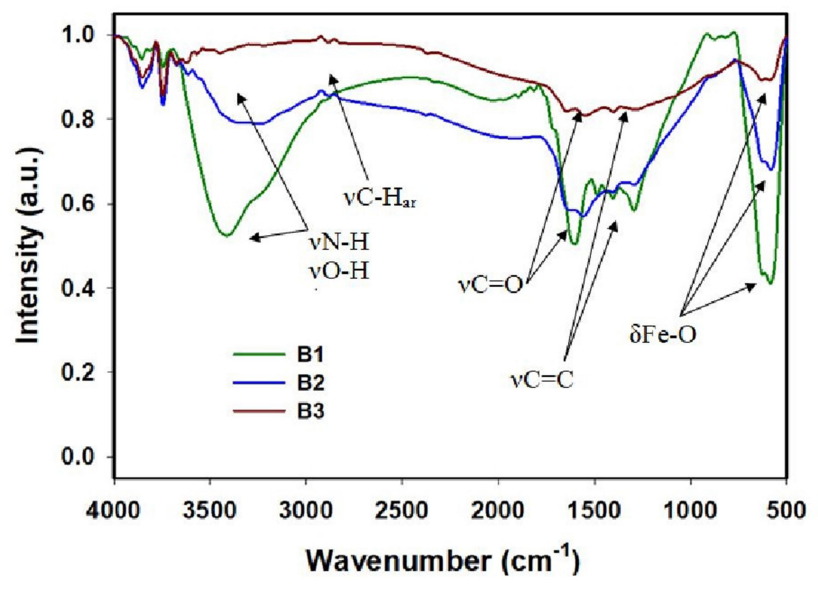

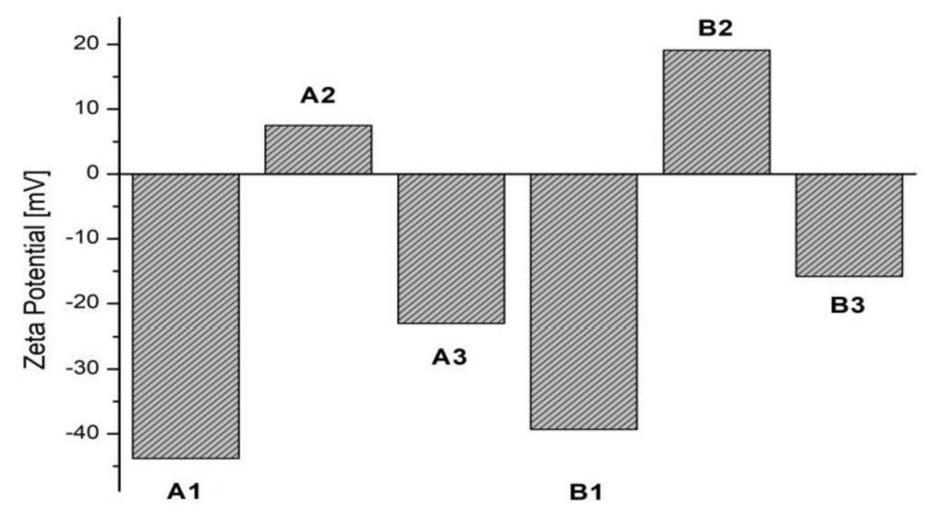

Figure 3 FTIR spectra for materials AI-A3 (A) and BI-B3 (B). Zeta potential for all obtained materials (C).

repulsion between positively charged moieties and leads to drug release and its further protonation, which increases the solubility of the drug in the aqueous environment.

\section{The Activity of Nanomaterials in Chemo- and Photothermal Liver Cancer Therapy in vitro}

The cytotoxicity toward the normal liver epithelial cells of the synthesized materials was evaluated through WST-1 and Live/Dead assays (SI Figure 5). The results showed concentration-dependent toxicity for both types of particles (A and B) according to cell metabolic activity measurement (SI Figure 5a and b). By contrast, in fluorescent Live/Dead cell viability assay, the ratios of alive to dead cells after incubation with analyzed materials were similar to the control cells (SI Figure 5c and d). We observed that the cells remain vital; however, their proliferation activity was inhibited with increasing concentration of particles. It is worth mentioning that the cytotoxic effect depends on functionalization of the particles. The best results were obtained for A1 and B1 NPs, in agreement with the recent reports showing that PDA-covered magnetite-based particles are characterized by reduced toxicity. ${ }^{49,50}$ It was shown that coating A1 and B1 NPs with PAMAM dendrimers decreases the cell viability. This is due to the positive charge of the particles and increased interaction with negatively charged membranes. ${ }^{51}$ Further functionalization of $\mathrm{A} 2$ and $\mathrm{B} 2$ materials with PEG improved their biocompatibility. This polymer is hydrophilic and uncharged, which could prevent recognition of nanoparticles by the mononuclear phagocyte system (MPS). ${ }^{52}$

In the next step, the in vitro photothermal effect of $\mathrm{A} 3$ and B3 materials on hepatocellular carcinoma HepG2 cells was assessed using WST-1 assay, together with Live/Dead cell staining and ROS determination. As shown in Figures 5A and $6 \mathrm{~A}$, cells maintained a high survival rate in the absence of the laser. As a contrast, reduced viability after laser ( $2 \mathrm{~W})$ irradiation for $5 \mathrm{~min}$ for cells treated with increased concentration of NPs was observed. Nanoparticles A3 at 
A

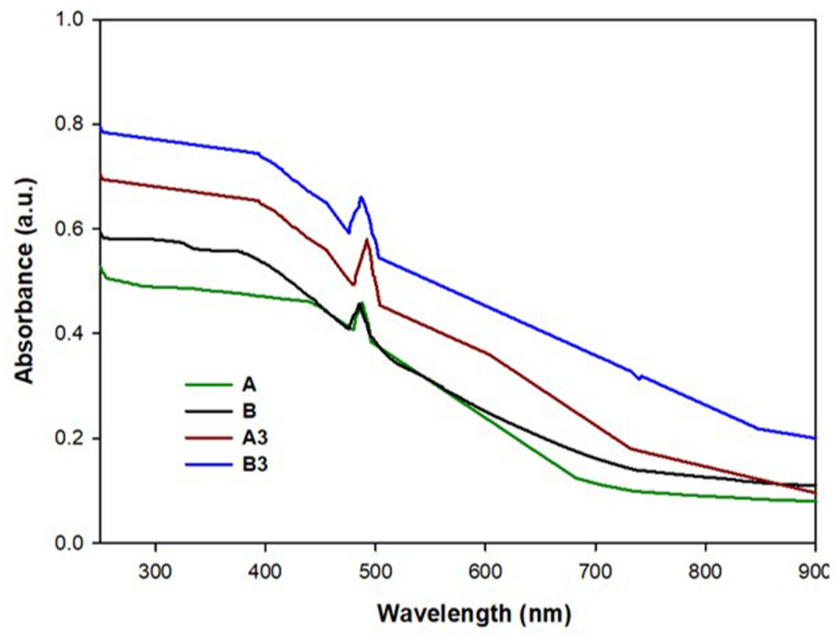

C

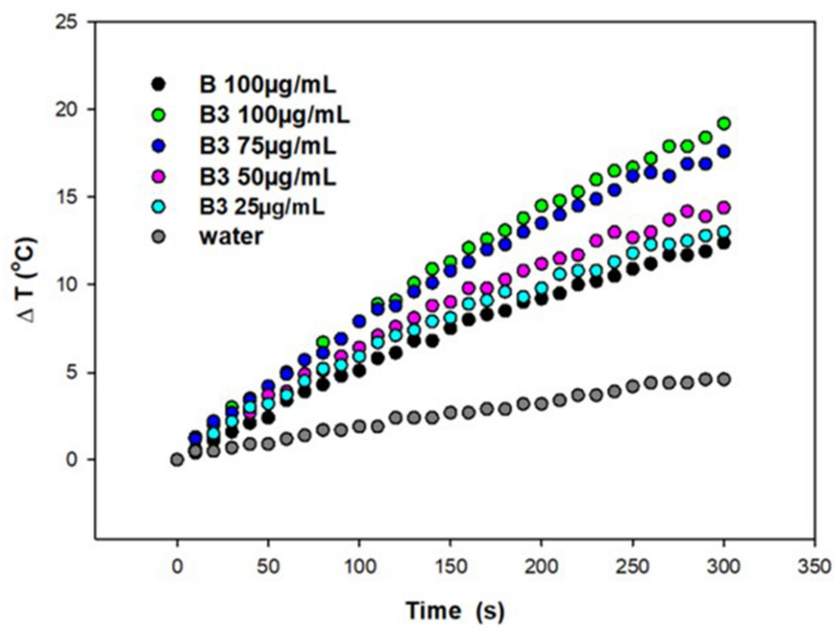

B

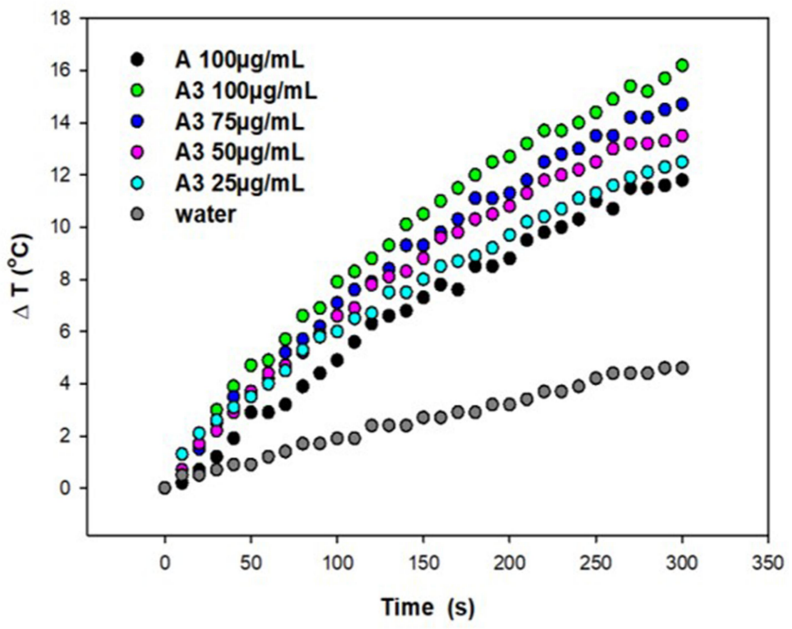

D

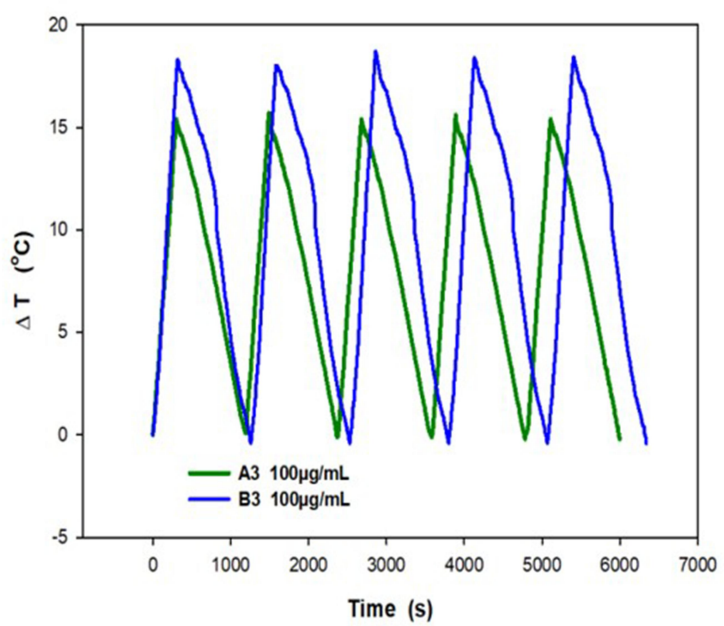

Figure 4 UV-Vis absorption spectra of materials $A, B$ and $A 3, B 3$ in a range $900-250 \mathrm{~nm}(\mathbf{A})$. Change of medium temperature caused by material $A 3$ (B) and B3 (C) at different concentrations vs material $A(100 \mu \mathrm{g} / \mathrm{mL})$ under NIR light irradiation $2 \mathrm{~W} / \mathrm{cm}^{2}$; photostability of materials $A 3$ and B3 $(100 \mu g / \mathrm{mL})$ under on/off cycles of NIR laser (D).

concentration of $20 \mu \mathrm{g} / \mathrm{mL}$ and $40 \mu \mathrm{g} / \mathrm{mL}$, cytotoxicity increased over $60 \%$ and $80 \%$ in +PTT group, respectively. For B3 NPs, this effect is even more pronounced. Magnetic spheres presented complete cell damage at a concentration of $40 \mu \mathrm{g} / \mathrm{mL}$ and nearly $90 \%$ decrease in cell viability at a concentration of $20 \mu \mathrm{g} / \mathrm{mL}$ in +PTT group. These results demonstrated the excellent photothermal therapy ability of analyzed materials. Calcein-AM and PI staining combined with fluorescence microscopy imaging was applied to further confirm the laser irradiation effect on tumor cells incubated with the particles. As shown in Figures 5B and 6B, A3- and $\mathrm{B} 3$-treated cells exhibited a red fluorescence signal at the highest concentration $(40 \mu \mathrm{g} / \mathrm{mL})$. It is a sign of membrane disruption during irradiation process because PI is a cellimpermeable dye that can only label dead cells. At lower concentrations a visible increase in the ratio of live to dead cells was demonstrated (green fluorescence signal from viable cells). These data are consistent with the WST-1 assay results. A negligible reduction in cell viability was observed for the control group without any treatment $(0(-\mathrm{L}))$ as well as the control group with laser treatment $(0(+\mathrm{L}))$. In addition, quantitative analysis of cells undergoing oxidative stress after PTT was performed by flow cytometry (Figure 5C and C). ROS level was measured in HepG 2 cells incubated for $4 \mathrm{~h}$ with $\mathrm{A} 3$ or B3 nanoparticles immediately $(0 \mathrm{~h})$ or $24 \mathrm{~h}$ after laser treatment. ROS profiles 


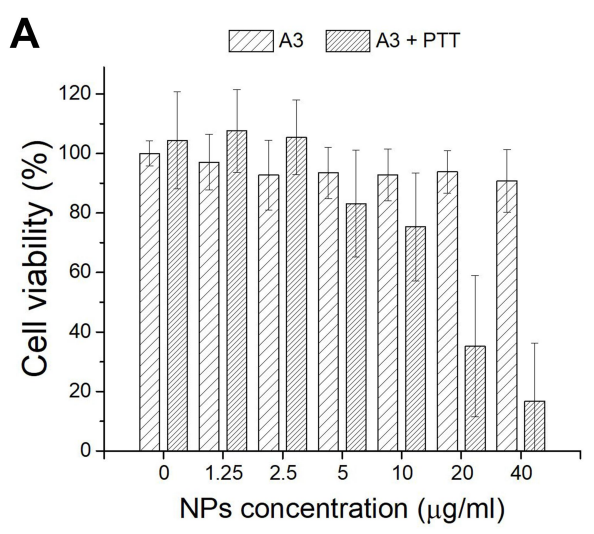

C

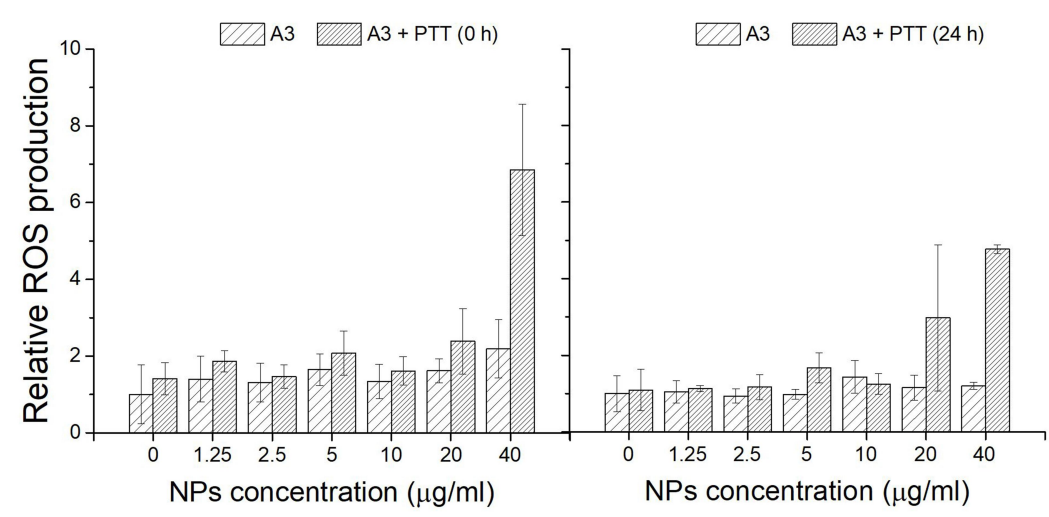

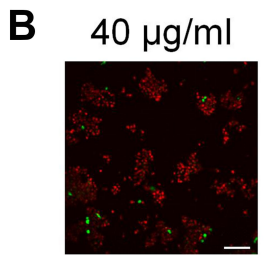
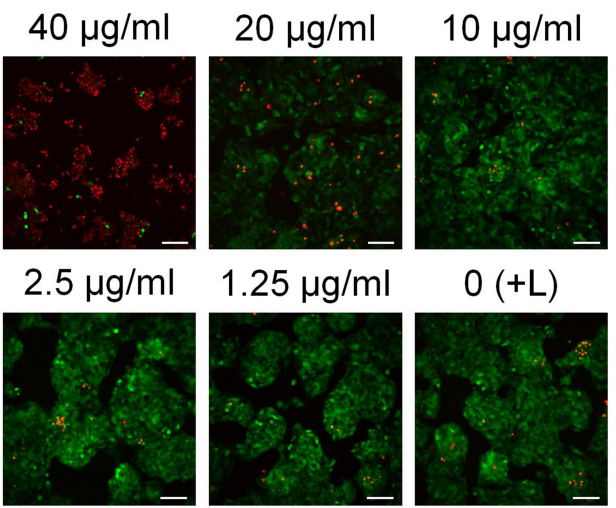

$0(+\mathrm{L})$
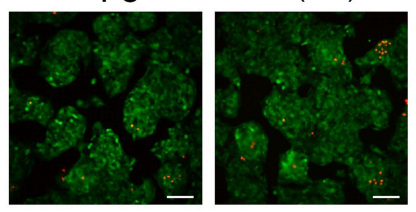

D

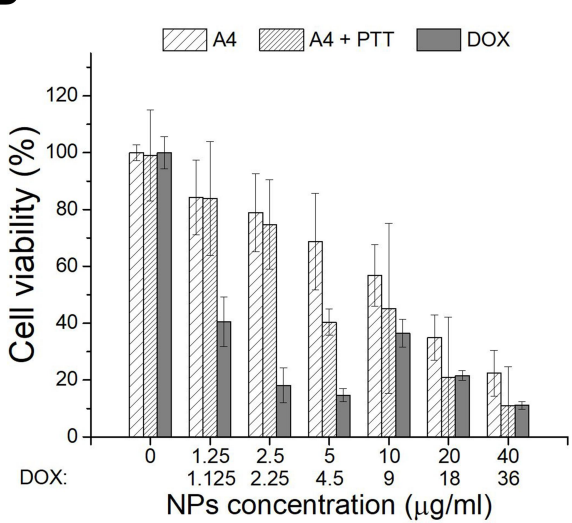

Figure 5 (A) Cell viability of HepG2 cells after 48 h incubation with A3 material and laser irradiation (2 W) for 5 min (A3 and A3 + PTT). (B) Images of HepG2 cells after incubation with A3 material and laser irradiation ( $2 \mathrm{~W}$ ) (A3+ PTT); calcein-AM stains for live cell (green); PI stains for dead cells (red); scale bar represents $100 \mu \mathrm{m}$. (C) Oxidative stress assay results for HepG2 cells after incubation with A3 material and laser irradiation (2 W) for 5 min (A3, A3 + PTT (0 h) and A3 + PTT (24 h)). (D) Cell viability of the HepG2 cells after incubation with A4 material and laser irradiation ( $2 \mathrm{~W})$ for 5 min in comparison to free drug (A4, A4 + PTT and DOX); ${ }^{2}$ < 0.05 .

used for calculation of relative ROS production are placed in Supporting Information (SI Figure 6 and SI Figure 7). As can be seen in Figure 5C, the ROS level is slightly raised with increasing concentration of nanomaterial A3. However, a significant increase in intracellular ROS level was found right after irradiation with a laser beam at concentration of 40 $\mu \mathrm{g} / \mathrm{mL}$. Moreover, elevated ROS level was still observed after $24 \mathrm{~h}$. Similar behaviour in ROS generation was observed for sample B3 both with and without NIR irradiation. However, it is important to highlight that the ROS level was already increased at lower particles concentration (10 $\mu \mathrm{g} / \mathrm{mL}$ ) incubated with HepG2 cells subjected to irradiation with NIR light (Figure 6C). These data suggest that oxidative stress is involved in the cytotoxic process caused by both nanoparticles and NIR laser irradiation. Treatment of cells only with laser beam did not trigger increment in ROS level. Particles themselves also did not cause such high increase of intracellular ROS. Based on the in vitro cell studies, we can claim that the analyzed nanoparticles were capable of efficiently damaging tumor cells through photothermal ablation and their toxicity was low without laser irradiation.

To investigate the chemotherapeutic effect of drug carriers, A4 or B4 nanoparticles were incubated with HepG2 cells and WST-1 assay was performed. As shown in Figure 5D and D, at low material concentration (up to $2.5 \mu \mathrm{g} / \mathrm{mL}$ ), the decrease in cell viability was not high. Further concentration increase of A4 and B4 NPs above $10 \mu \mathrm{g} / \mathrm{mL}$ reveals that their activity was comparable to free doxorubicin. It was found that free $\mathrm{DOX}$ had an $\mathrm{IC}_{50}$ value of $1.07 \mu \mathrm{g} / \mathrm{mL}$. It is worth highlighting that $\mathrm{B} 4$ material $\left(\mathrm{IC}_{50}=6.25 \mu \mathrm{g} / \mathrm{mL}\right.$ corresponding to $5.6 \mu \mathrm{g} / \mathrm{mL}$ of DOX) more strongly affected the HepG2 cells than the A4 material $\left(\mathrm{IC}_{50}=22.54 \mu \mathrm{g} / \mathrm{mL}\right.$ corresponding to 20.3 $\mu \mathrm{g} / \mathrm{mL}$ of DOX) in the measured concentration range. This can be attributed to larger size of particles of B4 and a different way of drug distribution. In the further stage, materials A4 and B4 in combined chemo- and photothermal therapy (CT-PTT) were investigated. The HepG2 cell viability for A4 material at concentration of $2.5 \mu \mathrm{g} / \mathrm{mL}$ 


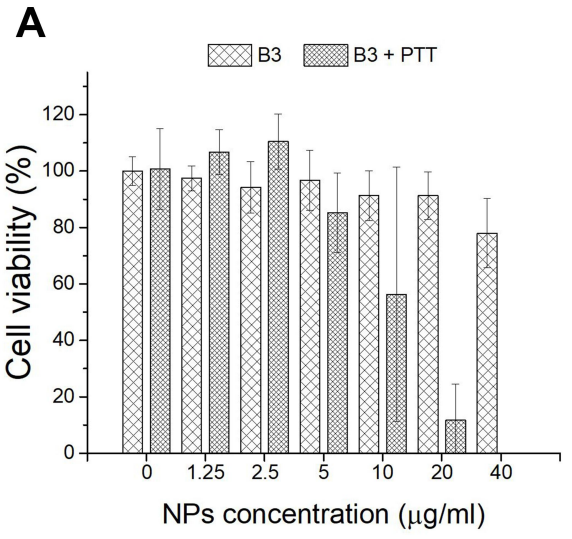

\section{C}

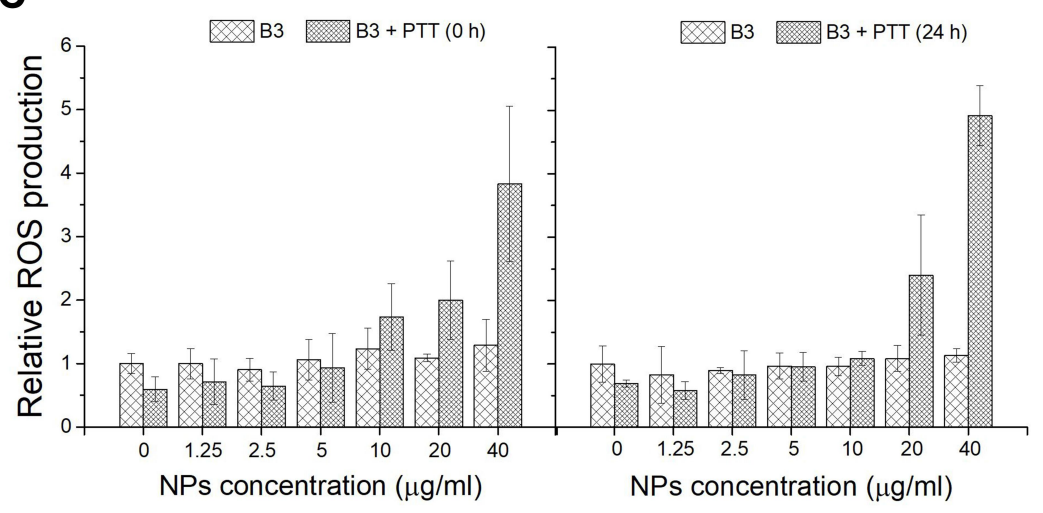

B
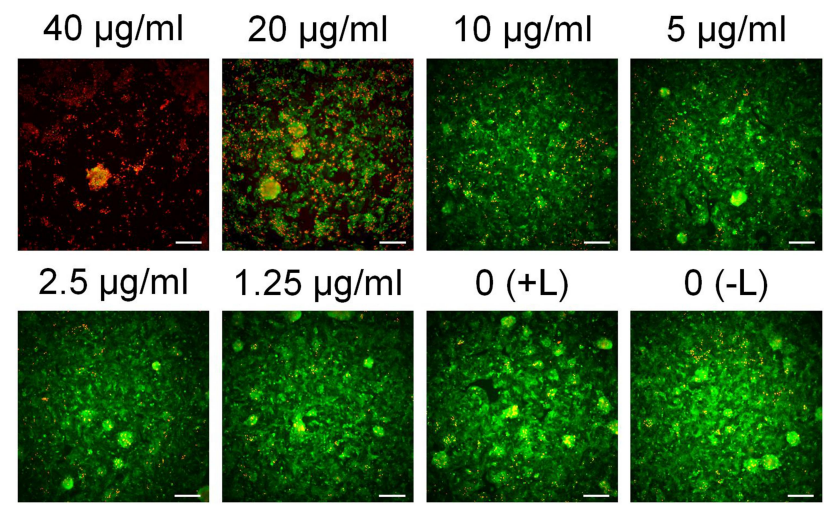

0 (-L)
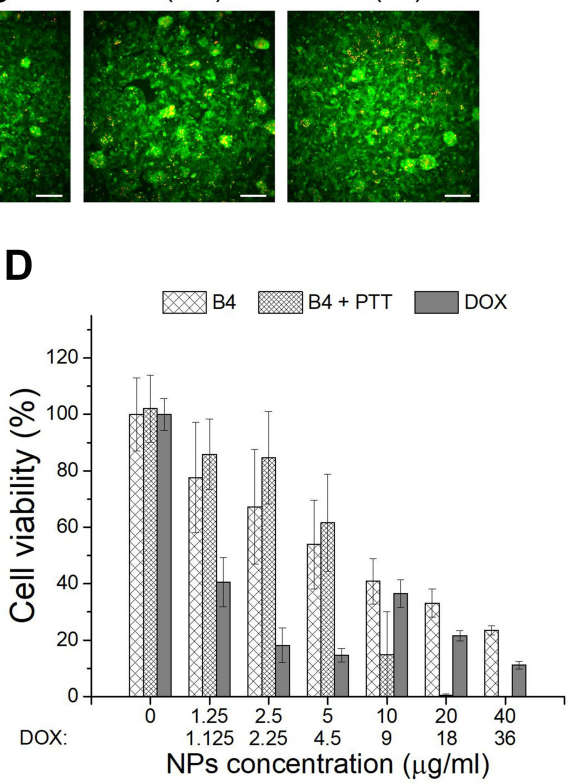

Figure 6 (A) Cell viability of HepG2 cells after $48 \mathrm{~h}$ incubation with B3 material and laser irradiation (2 W) for 5 min (B3 and B3 + PTT). (B) Images of HepG2 cells after incubation with B3 material and laser irradiation (2 W) (B3+ PTT); calcein-AM stains for live cell (green); PI stains for dead cells (red); scale bar represents I00 $\mu \mathrm{m}$. (C) Oxidative stress assay results for HepG2 cells after incubation with B3 material and laser irradiation (2 W) for 5 min (B3, B3 + PTT (0 h) and B3 + PTT (24 h)). (D) Cell viability of the HepG2 cells after incubation with B4 material and laser irradiation (2 W) for 5 min in comparison to free drug (B4, B4 + PTT and DOX).

and after NIR laser irradiation was similar compared to standard chemotherapy. The cell viability decreased by only $15 \%-20 \%$ in both cases. However, in the range of concentrations between 2.5 and $40 \mu \mathrm{g} / \mathrm{mL}$, we observed a significant drop of cell viability for nanomaterial A4 (up to $20 \%$ at the highest concentration) after laser irradiation. This phenomenon was assigned to an increasing concentration of material containing PDA which enhanced the photothermal effect and resulted in a more effective eradication of cancer cells in comparison to chemotherapeutic approach (at lower concentrations at $5 \mu \mathrm{g} / \mathrm{mL}$ ). The chemotherapeutic potential of irradiated A4 material increased fourfold as compared to non-irradiated nanoparticles $\left(\mathrm{IC}_{50}\right.$ $=5.4 \mu \mathrm{g} / \mathrm{mL}$ corresponding to $4.9 \mu \mathrm{g} / \mathrm{mL}$ of DOX). Similar behavior was found for B4 materials. As in the previous case, at low concentration range up $2.5 \mu \mathrm{g} / \mathrm{mL}$, we did not observe a sharp decrease in cell viabilities. Above this concentration, the viability of the cells went down to $70 \%, 20 \%$ and near $0 \%$ when the cells were incubated with B4 material at concentrations of 5, 10, and $20 \mu \mathrm{g} / \mathrm{mL}$, respectively. The $\mathrm{IC}_{50}$ values were similar for both irradiated $\left(\mathrm{IC}_{50}=6.1 \mu \mathrm{g} / \mathrm{mL}\right.$ corresponding to $5.45 \mu \mathrm{g} / \mathrm{mL}$ of $\mathrm{DOX})$ and non-irradiated $\left(\mathrm{IC}_{50}=6.25\right.$ $\mu \mathrm{g} / \mathrm{mL}$ corresponding to $5.6 \mu \mathrm{g} / \mathrm{mL}$ of DOX) B4 material.

Magnetic nanoparticles are an important class of nanomaterials frequently used for the preparation of carriers for drug delivery. ${ }^{53,54}$ They have drawn much attention because they can be obtained in different sizes and shapes, which is crucial for many biomedical applications. Moreover, they have been established as biocompatible materials and are approved by FDA. ${ }^{53-55}$ One of the most important features of magnetic nanoparticles is the ability to be steered to cancer tissue by external magnetic field. ${ }^{56,57}$ The latest publications have proven that dual therapies, ie combined chemo- and photothermal treatment, contribute to lower tumor growth and cancer regression due to the more efficient drug penetration to the adjacent cells in the tumor tissue. ${ }^{38,58}$ Therefore, novel magnetic nanoparticles have to fulfil those requirement. In our study, we covered the different sizes of magnetic 
nanoparticles with biomimetic polydopamine, which is considered a rising star in nanomedicine, ${ }^{59,60}$ to render our particles with strong photothermal properties. Indeed, the latest report shows that PDA-coated magnetic nanoparticles can serve as a drug carrier for doxorubicin ${ }^{41}$ to cancer cells or as an efficient magnetic photothermal agent in liver cancer treatment. ${ }^{24,61}$ However, none of those materials offer active targeting into tumor cells. In our case we developed a new strategy allowing the increase of encapsulation of hydrophobic drugs by combining different sizes of PDA-coated magnetic nanoparticles with PAMAM dendrimers. Furthermore, we showed a straightforward strategy for the surface modification of the obtained materials based on the bifunctional linker with active group ready for thiol-ene click reaction with different thiol derivatives. ${ }^{53,54,62}$ This approach is gaining more and more attention due to the mild reaction conditions and wide scope of easily available building blocks. In order to exemplify the versatility of our approach we attached the thiol derivative of folic acid which at same time ensures active targeting toward HCC cells overexpressing the folic acid receptors. Therefore, our materials give access to efficient combined chemoand photothermal therapy but should also diminish the side effects of chemotherapy due to their active targeting. We also proved that PDA-coated magnetic spheres were more efficient in therapies based on NIR irradiation because determined cell viabilities for those materials were lower than for the same concentrations of nanomaterials based on small magnetic nanoparticles. This was due to the higher absorption of NIR light by magnetic spheres in comparison to small magnetic nanoparticles. To the best of our knowledge the studies of reactive oxygen species generation by PDA-coated magnetic nanoparticles have not been carried out. Our studies revealed that different ROS species may play a role in the cancer cells death; thus, the first step toward understanding the mechanism of photothermal therapy using PDA-coated magnetic nanoparticles has been taken, and detailed studies are already ongoing in our laboratory.

\section{Conclusion}

In this work, we present two types of nanomaterials (nanoparticles and spheres) based on polydopamine and PAMAM dendrimers g.5.0 functionalized with NHS-PEG-Mal linker terminated with folic acid for in vitro hepatocellular carcinoma treatment. Our materials were characterized by TEM, FTIR, TGA, zeta potential measurements and exhibit low toxicity towards THLE-2 and HepG2 cells. We found that the magnetic spheres had stronger photothermal properties than magnetic nanoparticles in smaller size. Additionally, their PPT response could be enhanced by a polydopamine shell. Furthermore, loading of doxorubicin onto nanomaterials gave rise to efficient nanostructures applicable in dual chemo- and photothermal therapy of HCC which has been found to cause higher mortality of cancer cell than separately applied modalities. Moreover, the obtained results imply that in the death of a cancer cell under applied PTT conditions various forms of ROS could be involved. This will be the subject of our further studies in order to understand the nature of PTT in cancer treatment. Additionally, we show a new approach to functionalize dendrimers linked to PDA of magnetic nanostructures using thiol-ene click chemistry between thiolated folic acid and PEGylated linker bearing a maleimide moiety which opens new ways in their modification Thus, our results are of great importance in the field of dendrimer-modified magnetic nanoparticles and sheds new light on their characterization, functionalization and application in advanced anticancer therapy of HCC.

\section{Acknowledgments}

The financial support under research grant number LIDER/11/0055/L-7/15/NCBiR/2016 by The National Centre for Research and Development is kindly acknowledged. The authors thank Damian Maziukiewicz for help with statistical analysis.

\section{Disclosure}

The authors declare no conflict of interest.

\section{References}

1. Zhang $\mathrm{X}$, Leng $\mathrm{H}, \mathrm{Ng} \mathrm{H}$, et al. Drug delivery system targeting advanced hepatocellular carcinoma: current and future.ws. Nanomed Nanotech. 2016;12:853-869. doi:10.1016/j.nano.2015.12.381

2. Lin S, Hoffmann K, Schemmer P. Treatment of hepatocellular carcinoma: a systematic review. Liver Cancer. 2012;1:144-158. doi:10.1159/ 000343828

3. McGlynn KA, Petrick JL, London WT. Global epidemiology of hepatocellular carcinoma: an emphasis on demographic and regional variability. Clin Liver Dis. 2015;19:223-238. doi:10.1016/j.cld.2015.01.001

4. Liver Cancer Report 2018, American Institute for Cancer Research, ISBN: 978-1-912259-38-0; 2018 World Cancer Research International. 2018.

5. Singal AG, El-Serag HB. Hepatocellular carcinoma from epidemiology to prevention: translating knowledge into practice. Clin Gastroenterol Hepatol. 2015;13:2140-2151. doi:10.1016/j.cgh.2015.08.014

6. Petrick JL, Braunlin M, Laversanne M, et al. International trends in liver cancer incidence, overall and by histologic subtype, 1978-2007. Int J Cancer. 2016;139:1534-1545. doi:10.1002/ijc.30211

7. Sia D, Villanueva A, Friedman SL, Llovet JM. Liver cancer cell of origin, molecular class, and effects on patient prognosis. Gastroenterology. 2017;152:745-761. doi:10.1053/j.gastro.2016.11.048 
8. Ganji SRR, Benton L, Pavitra E, Yu JS. Multifunctional nanoparticles: recent progress in cancer therapeutics. Chem Commun. 2015;51:13248-13259. doi:10.1039/C5CC04643B

9. Han Y, An Y, Jia G, et al. Theranostic micelles based on upconversion nanoparticles for dual-modality imaging and photodynamic therapy in hepatocellular carcinoma. Nanoscale. 2018;10:6511-6523. doi:10.1039/C7NR09717D

10. Fan Z, Fu PP, Yu H, Ray PC. Theranostic nanomedicine for cancer detection and treatment. J Food Drug Anal. 2014;22:3-17. doi:10.1016/j.jfda.2014.01.001

11. Liu D, Yang F, Xiong F, Gu N. The smart drug delivery system and its clinical potential. Theranostics. 2016;6:1306-1323. doi:10.7150/ thno. 14858

12. Liang PC, Chen YC, Chiang CF, et al. Doxorubicin-modified magnetic nanoparticles as a drug delivery system for magnetic resonance imaging-monitoring magnet-enhancing tumor chemotherapy. Int J Nanomed. 2016;11:2021-2037.

13. Sivakumar B, Aswathy RG, Romero-Aburto R, et al. Highly versatile SPION encapsulated PLGA nanoparticles as photothermal ablators of cancer cells and as multimodal imaging agents. Biomater Sci. 2017;5:432-443. doi:10.1039/C6BM00621C

14. Shin T-H, Choi Y, Kim S, Cheon J. Recent advances in magnetic nanoparticle-based multi-modal imaging. Chem Soc Rev. 2015;44:4501-4516. doi:10.1039/C4CS00345D

15. Zhang $\mathrm{H}, \mathrm{Li} \mathrm{J}, \mathrm{Hu} \mathrm{Y}$, et al. Folic acid-targeted iron oxide nanoparticles as contrast agents for magnetic resonance imaging of human ovarian cancer. J Ovarian Res. 2016;9:19. doi:10.1186/s13048-016$0230-2$

16. Lee K, David AE, Zhang J, et al. Enhanced accumulation of theranostic nanoparticles in brain tumor by external magnetic field mediated in situ clustering of magnetic nanoparticles. $J$ Ind Eng Chem. 2017;54:389-397. doi:10.1016/j.jiec.2017.06.019

17. Gobbo OL, Sjaastad K, Radomski MW, et al. Magnetic nanoparticles in cancer theranostics. Theranostics. 2015;5:1249-1263. doi:10.7150/ thno. 11544

18. Revia RA, Zhang M. Magnetite nanoparticles for cancer diagnosis, treatment, and treatment monitoring. Materials Today. 2016;19:157-168. doi:10.1016/j.mattod.2015.08.022

19. Kim M, Lee JH, Nam JM. Plasmonic photothermal nanoparticles for biomedical applications. Adv Mater. 2019;4. doi:10.1002/ advs.201900471.

20. Khot MI, Andrew H, Svavarsdottir HS, et al. A review on the scope of photothermal therapy-based nanomedicine in preclinical models of colorectal cancer. Clin Colorectal Cancer. 2019;18:200-209. doi:10.1016/j.clcc.2019.02.001

21. Hu JJ, Cheng YJ, Zhang XZ. Recent advances in nanomaterials for enhanced photothermal therapy of tumors. Nanoscale. 2018;10:22657-22672. doi:10.1039/C8NR07627H

22. Hussein EA, Zagho MM, Nasrallah GK, Elzatahry AA. Recent advances in functional nanostructures as cancer photothermal therapy. Int J Nanomedicine. 2018;13:2897-2906. doi:10.2147/IJN.S161031

23. Estelrich J, Busquets MA. Iron oxide nanoparticles in photothermal therapy. Molecules. 2018;23:1567. doi:10.3390/molecules23071567

24. Wu M, Da Z, Zeng Y, Wu L, Liu X, Liu J. Nanocluster of superparamagnetic iron oxide nanoparticles coated with poly (dopamine) for magnetic field-targeting, highly sensitive MRI and photothermal cancer therapy. Nanotechnology. 2015;26:115102. doi:10.1088/09574484/26/11/115102

25. Xue P, Sun L, Li Q, et al. PEGylated polydopamine-coated magnetic nanoparticles for combined targeted chemotherapy and photothermal ablation of tumour cells. Colloids Surf B. 2017;160:11-21. doi:10.1016/j.colsurfb.2017.09.012

26. Zheng R, Wang S, Tian Y, et al. Polydopamine-coated magnetic composite particles with an enhanced photothermal effect. ACS Appl Mater Interfaces. 2015;7:15876-15884. doi:10.1021/acsami. $5 \mathrm{~b} 03201$
27. Shen S, Wang S, Zheng R, Zhu X, Jiang X, Fu DW. Magnetic nanoparticle clusters for photothermal therapy with near-infrared irradiation. Biomaterials. 2015;39:67-74. doi:10.1016/j.biomaterials.2014.10.064

28. Zhang X, Xu X, Li T, et al. Composite photothermal platform of polypyrrole-enveloped $\quad \mathrm{Fe}_{3} \mathrm{O}_{4} \quad$ nanoparticle self-assembled superstructures. ACS Appl Mater Interfaces. 2014;6:14552-14561. doi:10.1021/am503831m

29. Lee H, Dellatore SM, Miller WM, Messersmith PB. Mussel-inspired surface chemistry for multifunctional coatings. Science. 2007;318:426-430. doi:10.1126/science.1147241

30. Qu K, Wang Y, Vasileff A, Jiao Y, Chen H, Zheng Y. Polydopamineinspired nanomaterials for energy conversion and storage. $J$ Mater Chem A. 2018;6:21827-21846. doi:10.1039/C8TA05245J

31. Xiong S, Wang $\mathrm{Y}$, Yu J, et al. Polydopamine particles for next-generation multifunctional biocomposites. $J$ Mater Chem A. 2014;2:7578-7587. doi:10.1039/C4TA00235K

32. Lee H, Park E, Lee H. Polydopamine and its derivative surface chemistry in material science: a focused review for studies at KAIST. $A d v$ Mater. 2020;32(35):1907505. doi:10.1002/adma.201907505

33. Mrówczyński R. Polydopamine-based multifunctional (nano)materials for cancer therapy. ACS Appl Mater Interfaces. 2018;10:7541-7561. doi:10.1021/acsami.7b08392

34. Schanze KS, Lee H, Messersmith PB. Ten years of polydopamine: current status and future directions. ACS Appl Mater Interfaces. 2018;10:7521-7522. doi:10.1021/acsami.8b02929

35. Zhu Z, Su M. Polydopamine nanoparticles for combined chemo- and photothermal cancer therapy. Nanomaterials. 2017;7:160. doi:10.3390/nano7070160

36. Liu G, Gao N, Zhou Y, et al. Polydopamine-based "four-in-one" versatile nanoplatforms for targeted dual chemo and photothermal synergistic cancer therapy. Pharmaceutics. 2019;11:50. doi:10.3390/ pharmaceutics 11100507

37. Batul R, Tamanna T, Khaliq A, Yu A. Recent progress in the biomedical applications of polydopamine nanostructures. Biomater Sci. 2017;5:1204-1229. doi:10.1039/C7BM00187H

38. Mrówczyński R, Jędrzak A, Szutkowski K, et al. Cyclodextrin-based magnetic nanoparticles for cancer therapy. Nanomaterials. 2018;8:170. doi:10.3390/nano8030170

39. Guo H, Sun H, Zhu H, et al. Synthesis of Gd-functionalized Fe3O4 @polydopamine nanocomposites for T1/T2 dual-modal magnetic resonance imaging-guided photothermal therapy. $N \mathrm{~J}$ Chem. 2018;42:7119-7124. doi:10.1039/C8NJ00454D

40. Lin LS, Cong ZX, Cao JB. Multifunctional $\mathrm{Fe}_{3} \mathrm{O}_{4} @$ Polydopamine core-shell nanocomposites for intracellular mRNA detection and imaging-guided photothermal therapy. ACS Nano. 2014;8:3876-3883. doi: $10.1021 / \mathrm{nn} 500722 \mathrm{y}$

41. Mrówczyński R, Jurga-Stop J, Markiewicz R, et al. Assessment of polydopamine coated magnetic nanoparticles in doxorubicin delivery. RSC Adv. 2016;6:5936-5943. doi:10.1039/C5RA24222C

42. Xuan S, Wang YXJ, Yu JC, Leung KCF. Tuning the grain size and particle size of superparamagnetic $\mathrm{Fe}_{3} \mathrm{O}_{4}$ microparticles. Chem Mater. 2009;21:5079-5087. doi:10.1021/cm901618m

43. Wang Y, Wang J, Gao M, Zhang X. An ultra hydrophilic dendrimer-modified magnetic graphene with a polydopamine coating for the selective enrichment of glycopeptides. $J$ Mater Chem B. 2015;3:8711-8716. doi:10.1039/C5TB01684C

44. Kandasamy G, Maity D. Recent advances in superparamagnetic iron oxide nanoparticles(SPIONs) for in vitro and in vivo cancer nanotheranostics. Int $J$ Pharm. 2015;496:191-218. doi:10.1016/j. ijpharm.2015.10.058

45. Mitra A, Mohapatra J, Meena SS, et al. Verwey transition in ultrasmall-sized octahedral $\mathrm{Fe} 3 \mathrm{O} 4$ nanoparticles. J Phys Chem C. 2014;118:19356-19362. doi:10.1021/jp501652e

46. Goya GF, Berquó TS, Fonseca FC, Morales MP. Static and dynamic magnetic properties of spherical magnetite nanoparticles. $J$ Appl Phys. 2003;94:3520. doi:10.1063/1.1599959 
47. Andrzejewski B, Bednarski W, Kaźmierczak M, et al. Magnetization enhancement in magnetite nanoparticles capped with alginic acid. Compos Part B Eng. 2014;64:147-154. doi:10.1016/j.compositesb. 2014.04.022

48. Śmiłowicz M, Pogorzelec-Glaser K, Łapiński A, et al. Spectroscopic and quantum chemical studies of interaction between the alginic acid and $\mathrm{Fe}_{3} \mathrm{O}_{4}$ nanoparticles, Spectrochim. Acta A Mol Biomol Spectrosc. 2017;182:1-7. doi:10.1016/j.saa.2017.03.056

49. Lendzion-Bieluń Z, Wojciechowska A, Grzechulska-Damszel J, et al. Effective processes of phenol degradation on $\mathrm{Fe}_{3} \mathrm{O}_{4}-\mathrm{TiO}_{2}$ nanostructured magnetic photocatalyst. J Phys Chem Solids. 2020;136:109178. doi:10.1016/j.jpcs.2019.109178

50. Woźniak A, Walawender M, Tempka $\mathrm{D}$, et al. In vitro genotoxicity and cytotoxicity of polydopamine-coated magnetic nanostructures. Toxicol in Vitro. 2017;44:256-265. doi:10.1016/j.tiv.2017.07.022

51. Shao XR, Wei XQ, Song X, et al. Independent effect of polymeric nanoparticle zeta potential/surface charge, on their cytotoxicity and affinity to cells. Cell Prolif. 2015;48:465-474. doi:10.1111/cpr.12192

52. Suk JS, Xu Q, Kim N, et al. PEGylation as a strategy for improving nanoparticle-based drug and gene delivery. Adv Drug Deliv Rev. 2016;99:28-51. doi:10.1016/j.addr.2015.09.012

53. Price PM, Mahmoud WE, Al-Ghamdi AA, Bronstein ML. Magnetic drug delivery: where the field is going. Front Chem. 2018;6. doi:10.3389/fchem.2018.00619.

54. Vangijzegem T, Stanicki D, Laurent S. Magnetic iron oxide nanoparticles for drug delivery: applications and characteristics. Expert Opin Drug Del. 2018;16:69-78. doi:10.1080/17425247.2019.1554647

55. Thakor AS, Jokerst JV, Ghanouni P, et al. Clinically approved nanoparticle imaging agents. J Nucl Med. 2016;57:1833-1837. doi:10.2967/jnumed.116.181362
56. Subramanian M, Miaskowski A, Jenkins SI, et al. Remote manipulation of magnetic nanoparticles using magnetic field gradient to promote cancer cell death. Appl Phys A. 2019;125:226. doi:10.1007/ s00339-019-2510-3

57. Hashemi-Moghaddam H, Kazemi-Bagsangani S, Jamili M, Zavareh S. Evaluation of magnetic nanoparticles coated by 5-fluorouracil imprinted polymer for controlled drug delivery in mouse breast cancer model. Int J Pharm. 2016;497:228-238. doi:10.1016/j.ijpharm.2015.11.040

58. Jędrzak A, Grześkowiak BF, Coy E, et al. Dendrimer based theranostic nanostructures for combined chemo- and photothermal therapy of liver cancer cells in vitro. Colloid Surf B: Biointerfaces. 2019;173:698-708. doi:10.1016/j.colsurfb.2018.10.045

59. Park J, Moon H, Hong S. Recent advances in melanin-like nanomaterials in biomedical applications: a mini review. Biomater Res. 2019;23. doi:10.1186/s40824-019-0175-9.

60. Jin A, Wang Y, Lin K, Jiang L. Nanoparticles modified by polydopamine: working as "drug" carriers. Bioact Mater. 2020;5:522-541. doi:10.1016/j.bioactmat.2020.04.003

61. Wu M, Wang Q, Zhang D, et al. Magnetite nanocluster@poly(dopamine)-PEG@ indocyanine green nanobead with magnetic field-targeting enhanced MR imaging and photothermal therapy in vivo. Colloid Surface B. 2016;141:467-475. doi:10.1016/j.colsurfb.2016.02.022

62. Kharkar PM, Rehmann SM, Skeens KM, et al. Thiol-ene click hydrogels for therapeutic delivery. ACS Biomater Sci Eng. 2016;2:165-179. doi:10.1021/acsbiomaterials.5b00420
International Journal of Nanomedicine

\section{Publish your work in this journal}

The International Journal of Nanomedicine is an international, peerreviewed journal focusing on the application of nanotechnology in diagnostics, therapeutics, and drug delivery systems throughout the biomedical field. This journal is indexed on PubMed Central, MedLine, CAS, SciSearch ${ }^{\mathbb{}}$, Current Contents ${ }^{\mathbb{R}} /$ Clinical Medicine, $^{-}$

\section{Dovepress}

Journal Citation Reports/Science Edition, EMBase, Scopus and the Elsevier Bibliographic databases. The manuscript management system is completely online and includes a very quick and fair peer-review system, which is all easy to use. Visit http://www.dovepress.com/ testimonials.php to read real quotes from published authors. 